\title{
Trial Production of a Vane-Tipe Pneumatic Linear Actuator
}

\author{
Masaru DANNO, Shoji SHIBATA, \\ Toshiyuki ASAKURA, and Shoji HAYASHI
}

\begin{abstract}
A specially constructed pneumatic actuator has been manufactured on a trial basis. This actuator is meritorious in that it does not have a rod such as an air cylinder and has a considerably long stroke. The principle of this actuator is similar in construction to air motors, and the driving object mounted on a vane moves along a grooved bench. The groove base is in the shape of a rack with wide pressure angles. The air pressure is supplied to the space which is composed of the vane and rack, and then the driving object is moved by vane-applied air pressure. The air leakage passing through the narrow slits of the actuator must be avoided to obtain good moving performance. This report has investigated both theoretically and experimentally the processing accuracy of the device to obtain excellent performance considering the air leakage from the narrow slits.
\end{abstract}

Key Words : Fluid Power Systems, Vane-type Pneumatic Actuator, Air Motor, Air Cylinder, Air Leakage

\section{1. 緒}

近年ロッドをもたないエアシリンダが, 実用化され てきている(1).ここで報告するアクチュエータもロッ ドレスアクチュエータと称するもので, エアモータの ようなベーンをもつ構造, 原理で直線運動を行うよう にしたものである.すなわちU字溝をもつレールの底 部を大きい圧力角をもつラックの形状とし，この溝内 にエアモータのようにベーンが出入りする駆動体があ って, ベーンは駆動体の運動に応じて出入りするよう になっている.このラックと駆動体抢よびベーンとに よって形成する三角状空間（以下これを溝という）内 に空気压を作用させると，この圧力がベーンに作用し て，駆動体はレール上を運動する.このとき，しゅう動 部からの空気の漏えいが大きいと，不必要に空気を消 費し，管路抵抗などにより溝内の圧力が大きく低下す る.そこで，駆動体に十分な推進力を与えるためには， 高精度の加工によって, しゅう動部からの空気の漏え いを極力小さくすることが必要である，本研究はこの ようなアクチュエータの試作結果を述べ, 十分な性能

* 昭和 62 年 7 月 14 日 東海支部三重地放講演会において蹒 演，原稿受付 昭和 63 年 3 月 7 日.

*2 正員, 福并大学工学部 ( 910 福井市文京 3-9-1).

*2 学生員, 福井大学大学院.
をもたせるために必要な加工精度を理論と実験の両面 から検討したものである。

\section{2. 原理, 構造ならびに実験装置}

図 1 に本機の構造を示す. B はラック形状底面の U 字形溝をもつレールである.駆動体 A には出入りする 2 枚のベーン 1 および 2 があって, 図 1 に向かい右方 向に駆動させる場合, 空気流入口 $E_{1}, E_{2}$ より,この ベーンに空気圧を作用させ, 駆動体 Aに推力を与え る構造となっている. ベーン $1 ， 2$ には同時に空気圧 が作用するが，二つのベーンの加圧面積の和は駆動体 の位置に関係なく，常に一定 $\left(6 \mathrm{~cm}^{2}\right)$ となるように設 計されている.したがって, 駆動体に働く推力はレー

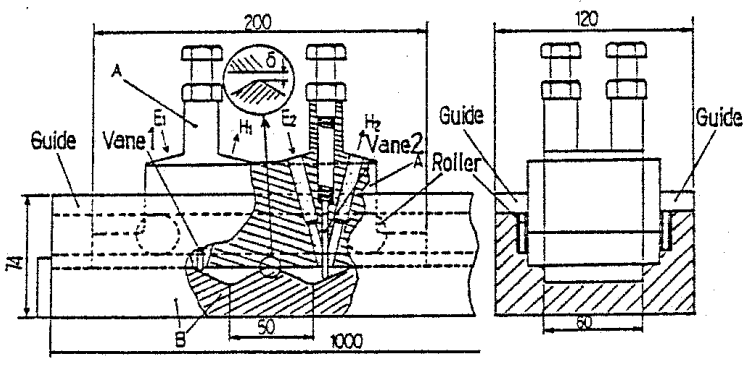

図 1 試作したアクチュエータの断面図 
ル上の位置に関係なく常に一定となる，駆動方向の変 更は空気流入口 $E_{1}, E_{2}$ を $H_{1}, H_{2}$ に切換えることによ $\eta$ 行う.このとき $E_{1}, E_{2}$ は排気口となる。空気压は駆 動体 A に推力を与えるとともに駆動体を上方に持ち 上げる力としても作用するので，ガイドによってこれ を防いている.ガイドと駆動体はローラによって転が り接触となるようにし，しゅう動の抵抗を小さくし た。なお，このアクチュエータは初めての試作で，十分 な加工精度を得ることができなかったため、しゅう動 部から無視し得ない空気の漏えいが認められた。この 漏えいの主要部は図 1 中の円内に示すラック形状の山

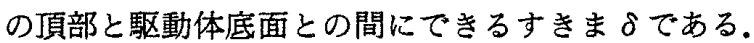
この $\delta$ の值をシックネスゲージによって計剆したと ころ,駆動体の位置によって多少差異はあるが 150〜180 $\mu \mathrm{m}$ 程度であった. その他の部分からの漏え いはわずかであるが考慮に入れて漏れ流量と圧力損失 の測定功，流れをオリフィス流れと近似して $\delta$ の值 を計算したところ平均 $220 \mu \mathrm{m}$ となった. よって, 理論 的取扱いにはすきま $\delta$ は他の漏えいも含めて $220 \mu \mathrm{m}$ とした。

本機の性能試験装置を図 2 に示す。駆動体にはコン プレッサからの空気をフィルタおよび弁を通した後， ビニール管を経由して供給する．駆動体の変位, 速度 および加速度は電気抵抗線と駆動体に取付けられてい るブラシによってポテンシオメータを構成し，この出 カをノイズフィルタ, A-D コンバー夕を経て, 計算機 処理を行い求めるようになっている.

\section{3. 記 号}

$a:$ ベーンの有効受圧面積 $\mathrm{m}^{2}$

$A_{1}, A_{2}$ : 管内断面積 $\mathrm{m}^{2}$

$b_{1}, b_{2}$ : 流入口および流出口面積比 $=S_{1} / S_{2}, S_{3} / S_{2}$

$d:$ 管内径 (4mm)

$F:$ 定数 $f$ の無次元量 $=f \cdot T_{m} / M$

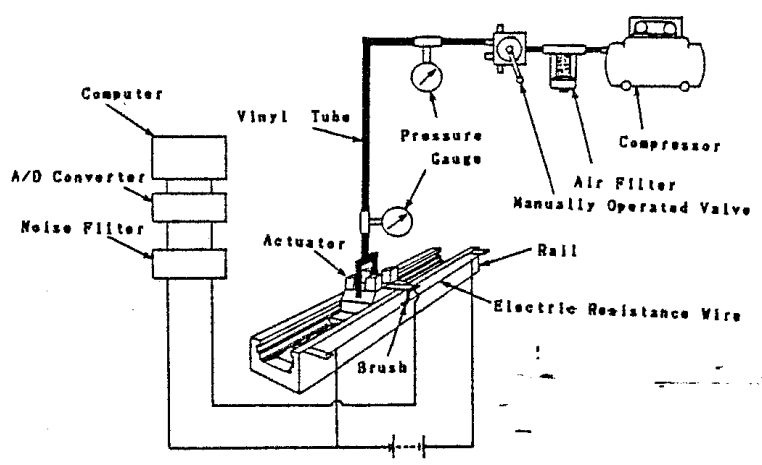

図 2 性能試験装置

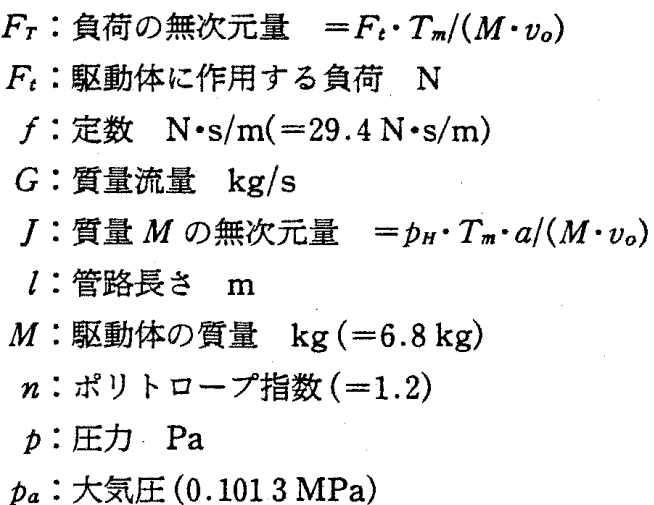

$p_{a}:$ 大気圧 $(0.1013 \mathrm{MPa})$

$p_{41}, p_{42}$ : ベーンの前および後の圧力 $\mathrm{Pa}$

$p_{H}:$ 溝内供給圧力 $=p_{3}$

$Q:$ 空気の体積流量 $\mathrm{m}^{3} / \mathrm{s}$

$R:$ 空気のガス定数 $\mathrm{J} /(\mathrm{kg} \cdot \mathrm{K})$ $[=287.1 \mathrm{~J} /(\mathrm{kg} \cdot \mathrm{K})]$

$r_{41}, r_{42}$ : 圧力 $p_{41}$ 抢よび $p_{42}$ の無次元量 $=p_{41} / p_{H}$ $p_{42} / p_{H}$

$S_{1}, S_{2}, S_{3}$ : 流入口，流出口および漏えい部の面積 $S_{1}$ $=S_{2}=9.8 \mathrm{~mm}^{2}, S_{3}=6 \mathrm{~cm} \times \delta$

$T$ :管内, および溝内温度 $(=293 \mathrm{~K})$

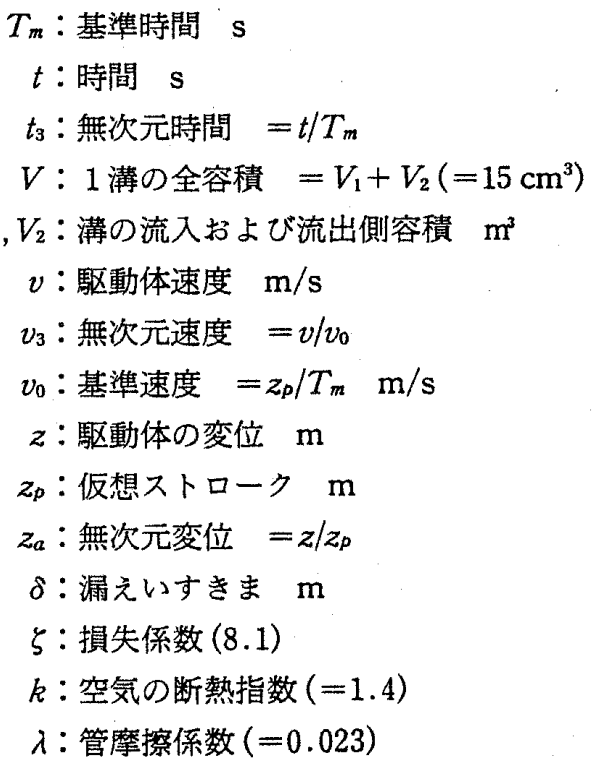

\section{4. 管路抵抗による圧力損失}

駆動体に空気の漏えいがない場合は駆動体につなが れている管路の圧力損失は無視し得るものと思われ る. しかし，本研究の上うに空気の漏えいを考慮にい 机ると管路抵抗による圧力損失量は無視することがで きないものとなる。 そこで, 図 3 に示す実験装置につ いて駆動体が静止しているものとし，コンプレッサか ら出た空気は長さ $l$ なる管路を通り，T形管で 2 方向 に分かれ，一方は $S_{1}$ なる流入口を経てベーンに圧力 として作用し， $S_{3}$ なるすきまから漏えいする， T 形管 
から分かれたもう一方は他のベーンに同様に作用す る.まず，長さけなる管路について，流れは等温的であ ると仮定し, 圧力と流量の関係を次式で与える.

$$
p_{1}{ }^{2}-p_{2}{ }^{2}=\frac{\lambda \cdot R \cdot T \cdot G_{1}{ }^{2} \cdot l}{d_{1} \cdot A_{1}{ }^{2}}
$$

ここでネは時間的加速度の項を含んだものとして実 験的に定め 0.023 を得た。

次に T 形管から溝までの圧力と流量の関係は曲が り部などを考慮に入れて次式によって表し，式中の は実験によって 8.1 なる值を得た。

$$
p_{2}{ }^{2}-p_{3}{ }^{2}=\zeta \frac{R T G_{2}{ }^{2}}{A_{2}{ }^{2}}
$$

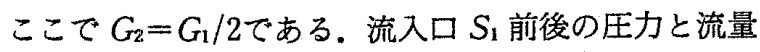
の関係はオリフィス流れとして次式で計算する。

$$
G_{2}=S_{1} \sqrt{2 \frac{x}{\kappa-1} \frac{p_{3}^{2}}{R T}\left\{\left(\frac{p_{4}}{p_{3}}\right)^{2 / \kappa}-\left(\frac{p^{4}}{p^{3}}\right)^{(\kappa+1) / \kappa}\right\}}
$$

同様に $S_{3}$ なるすきま前後の圧力と流量についてもオ リフィス流れと仮定し，式(3)の $p_{3}$ を $p_{4} に, p_{4}$ を $p_{a}$ に，および $S_{1}$ を $S_{3}$ に置き換えることにより計算し た。漏えいが臨界条件以上（音速域）の場合は次式に より計算した。

$$
G_{2}=S_{3} \sqrt{2 \frac{x}{\varkappa+1}\left(\frac{2}{\varkappa+1}\right)^{2 /(\kappa-1)} \cdot \frac{p_{4}{ }^{2}}{R T}}
$$

以上式(1)～(3) と式 (3)の記号を置き換えた式を 用いて繰返し計算を行い，任意に $p_{1}$ と $\delta$ を元た場 合の $p_{2}, p_{3}, p_{4}$ および $G_{1}$ を計算した。 そして， 5 章で 述べる解析方法により $p_{3}=p_{H}$ とすることですきま $\delta$ が与えられた場合の駆動体の運動特性を求めることが できる。なお，計算に当たっては空気の絶対温度 $T$ は 溝内流入時において断熱膨張によっていくぶん降下す るはずであるが, 実験的に調べたところほとんど変化 がなく，また計算上でもこの変化はあまり大きいもの

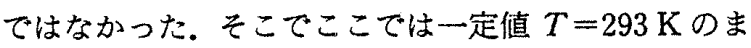
ま溝内へ流入するものとした.

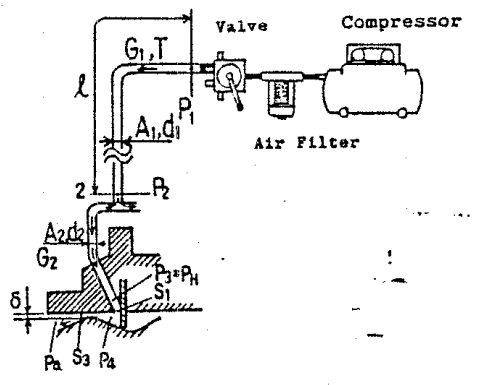

図 3 実験装置

\section{5. 駆動体の運動}

図 4 に示すように，まず 1 枚のベーンに作用する压 力と駆動体の運動について考える. 溝内への空気の流 入側についてベーンの移動による溝内の容積增分 $d V_{1}$ は式（5)によって与えられる.

$$
d V_{1}=d Q_{1}-\frac{V_{1}}{n p_{41}} d p_{41}
$$

式(5)右辺第 1 項はしゅう動部のすきま $\delta$ からの空 気漏えい量を差引いた溝内への有効空気流入量であ $\eta$, 第 2 項は圧力変化 $d p_{41}$ による体積変化を表して いる.

また，流出側についてベーンの移動による溝内容積 変化 $d V_{2}$ は式 $(6)$ によって与えられる.

$$
d V_{2}=-d Q_{2}-\frac{V_{2}}{n p_{42}} d p_{42}
$$

駆動体の運動方程式は次のようで,

$$
M \frac{d^{2} z}{d t^{2}}=\left(p_{41}-p_{42}\right) a-f \frac{d z}{d t}-F_{t}
$$

速度と変位の間には次の関係がある。

$$
\frac{d z}{d t}=v
$$

駆動体の運動解析に当たってはベーンの移動にともな う溝の時間的容積変化が駆動体の位置によって, 一様 でないため，図 4 に示すように溝を A, B, C, D の四つ の区間に分割して計算を進めた。また,べーンが区間 Aにある場合について考元よう。空気の流入, 流出, 漏えいはすべてオリフィスを通る流れとして取扱うも のとする.オリフィス前後の圧力差が臨界条件以下（覀 音速域）であるとすると，泟内へ流入する空気の溝内 圧力 $p_{41}$ における体積流量 $Q_{1}{ }^{(2)}$ は流入前後の圧力が $p_{H}$ および $p_{41}$ であるので，近似的に

$$
Q_{1}^{\prime}=3.78 \cdot 10^{-3} \cdot S_{1} \frac{p_{a}}{p_{41}} \cdot \sqrt{p_{41}\left(p_{H}-p_{41}\right)} \sqrt{\frac{T}{273}}
$$

溝内から漏えいする空気の体積流量 $Q_{1}$ " は先と同様 臨界条件以下の場合,

$$
Q_{1}^{\prime \prime}=3.78 \cdot 10^{-3} \cdot S_{3} \frac{p_{a}}{p_{41}}
$$

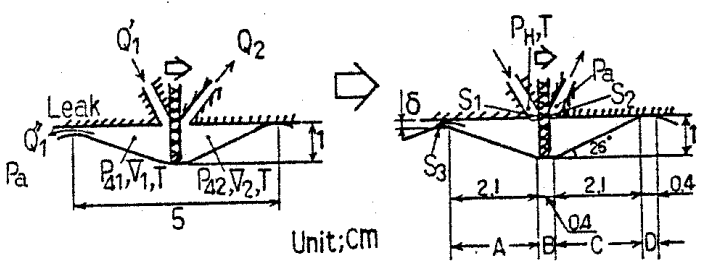

図 4 溝内の圧力, 流量と区間分割 


$$
\cdot \sqrt{p_{a}\left(p_{41}-p_{a}\right)} \sqrt{\frac{T}{273}}
$$

瑇内から漏えいが臨界条件以上でおこる場合はその体 積流量 $Q_{1 m} "$ は

$$
Q_{1 m} "=1.89 \cdot 10^{-3} \cdot S_{3} \cdot p_{a} \sqrt{\frac{T}{273}}
$$

によって与えられる.

今, 溝内人の空気の流入および漏えいが臨界条件以 下で行われるとき, 溝内への空気の有効流入体積流量 $d Q_{1}$ は $d Q_{1}=\left(Q_{1}^{\prime}-Q_{1}{ }^{\prime \prime}\right) d t$ で与えられ，

$$
\begin{aligned}
& d Q_{1}=3.78 \cdot 10^{-3} \cdot p_{a} \sqrt{\frac{T}{273}} \cdot\left\{S_{1} \sqrt{\frac{1}{r_{41}}-1}\right. \\
& \left.-S_{3} \sqrt{\frac{1}{r_{41} p_{a}}\left(1-\frac{1}{r_{41}} \frac{p_{a}}{p_{H}}\right)}\right\} d t
\end{aligned}
$$

さらに時間の無次元化を行うため, 式(13)に示すよう な基準時間 $T_{m}$ を考える(3).

$$
T_{m}=\frac{V}{1.89 \cdot 10^{-3} \cdot S_{2} \cdot p_{a}} \sqrt{\frac{273}{T}}
$$

この $T_{m}$ は「Vなる容積の溝内へ常に音速域で $S_{2}$ な る有効断面積を通して温度 $T$ なる空気が流入し, 真 空から供給圧まで溝内が等温変化をしながら満たされ ていく，と仮定したときに要する充てん時間」である. 式(5)に式(12)を代入し，両辺を式(13)で除し, 式 (14)を得る。

$$
\begin{aligned}
& \frac{d V_{1}}{V}=2\left\{b_{1}-\sqrt{\frac{1}{r_{41}}-1}\right. \\
& \left.-b_{2} \sqrt{\frac{1}{r_{41}} \frac{p_{a}}{p_{H}}\left(1-\frac{1}{r_{41}} \frac{p_{a}}{p_{H}}\right)}\right\} \\
& \text { - } \frac{d t}{T_{m}}-\frac{1}{n} \frac{V_{1}}{V} \frac{d r_{41}}{r_{41}}
\end{aligned}
$$

なお，空気の漏えいが臨界条件以上でおこる場合に ついては式(10)のかわりに式(11)を用いて同様の取扱 いを行えばよい.

さらに解析の便宜上，寸法の無次元化を行う. 区間 Aについては図 5 に示すように溝の斜面に沿って一 点鎖線で示すような延長した三角形状溝 $\mathrm{abc}$ を想定 する。このとき三角形状溝と実際の台形状溝 adef $の$ 容積が等しく(いずれも $\left.15 \mathrm{~cm}^{3}\right)$ なるような寸法 決める。このようにして決めた仮想的な寸法，すなわ ちストロークは $\overline{\mathrm{ac}}=z_{p}=3.24 \mathrm{~cm}$ となる。したがっ て, 区間 A の実際のストローク $z(0 \leqq z \leqq 2.1 \mathrm{~cm})$ は無 次元ストローク $z_{a}$ で表現すれば, $0 \leqq z_{a} \leqq 0.65$ とな る.このように考えると式(14)は式(15)のように表す ことができる。

$$
\begin{aligned}
& \frac{d r_{41}}{d t_{a}}=n r_{41} \frac{1}{z_{a}^{2}}\left[2 \left\{b_{1} \sqrt{\frac{1}{r_{41}}-1}\right.\right. \\
& \left.\left.-b_{2} \sqrt{\frac{1}{r_{41}} \frac{p_{a}}{p_{H}}\left(1-\frac{1}{r_{41}} \frac{p_{a}}{p_{H}}\right)}\right\}-2 \overline{z_{a}} \cdot v_{a}\right]
\end{aligned}
$$

同様にベーンの移動による空気流出側については式 (16)のようになる.

$$
\begin{aligned}
& \frac{d r_{41}}{d t_{a}}=n r_{42} \frac{1}{\left(1-z_{a}^{2}\right)} \\
& \cdot\left[-2 \sqrt{\left(\frac{1}{r_{41}} \frac{p_{a}}{p_{H}}\right)^{1 / n}\left(1-\frac{1}{r_{41}} \frac{p_{a}}{p_{H}}\right)}+2 z_{a} \cdot v_{a}\right]
\end{aligned}
$$

式(15)および式(16) 㹥無次元化されているため, 溝 の寸法に変更が加えられた場合にも成立する，以上は

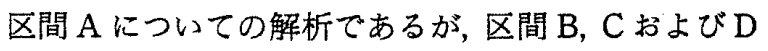
についても同様な取扱いで解析を進めた。

次に駆動体の運動方程式式 (7) は質量, 負荷などを 無次元化することにより，次のように表すこともで き,

$$
\frac{d v_{a}}{d t_{a}}=J\left(r_{41}-r_{42}\right)-F \cdot v_{a}-F_{T}
$$

無次元速度 $v_{a}$ は式(18)となる。

$$
\frac{d z_{a}}{d t_{a}}=v_{a}
$$

以上は便宜上，1枚のベーンについて説明した. 実 際は図 1 に示すように駆動体は 2 枚のベーンをもつの で, 同様の手法で関係式を導出し, 1 枚のベーンに関 する式(15)〜(18)，および他方のベーンに関する同様 の式と連立して,ルンダ・クッタ法による数值積分に よって 1 荆ずつ解くことにより, 駆動体の挙動を求め た.

\section{6. 簡 易 解 析}

5 章の解析は計算が煩雑で，かなりの時間を必要と する。 そこで溝内圧力 $p_{41}, p_{42}$ が一定と近似できる場合 (例えば，空気が十分に供給され，かつ排出されるよう に $S_{1}, S_{2}$ を大きくとった場合, あるいは駆動体速度が あまり大きくない場合など）は次に示す簡単な線形微 分方程式によって, 駆動特性を近似的に取扱うことが できる.

$$
M \frac{d^{2} z}{d t^{2}}=F^{\prime}-f \frac{d z}{d t}
$$

ここで $F^{\prime}$ は $F^{\prime}=\left(p_{41}-p_{42}\right) A-F_{t}$ となる定数項であ る.この場合は $p_{41}=p_{4}, p_{42}=p_{a}$ で与えられ, $A$ は 2 枚

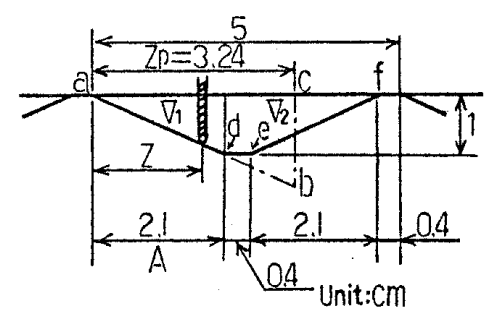

図 5 無次元化のための寸法設定 
のベーンの加圧面積の和 $\left(6 \mathrm{~cm}^{2}\right)$ である. $t=0$ のとき, $v$ $=0$ よよ゙ $z=0$ なる初期条件を用いて式(19)を解くと 次式を得る。

$$
\begin{aligned}
& z=\frac{F^{\prime}}{f}\left\{t+\frac{M}{f} \exp \left(-\frac{f}{M} t\right)\right\}-\frac{F^{\prime} M}{f^{2}} \\
& v=\frac{F^{\prime}}{f}\left\{1-\exp \left(-\frac{f}{M} t\right)\right\} \quad \cdots \cdots \cdots \cdots \cdots
\end{aligned}
$$

\section{7. 結果および考察}

さきに述べたように駆動体のしゅう動部からの空気 の漏えいが大きいと十分な性能が得られない.そこで, この漏えいすきま $\delta$ と装置内各部の圧力の低下の様 子, および漏れ流量との関係を理論によって計算し,

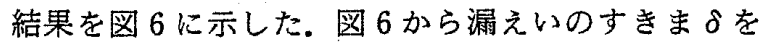
$100 \mu \mathrm{m}$ 程度以下となるように加工精度を上げると, 各部の圧力損失は急激に減少し, 漏九流量 $G_{1}$ も効果 的に減少することがわかる。つまり， $\delta$ は約 $100 \mu \mathrm{m}$ 以 下でなければ十分な性能は望めない.さらに， $\delta$ を 100 $\mu \mathrm{m}$ 以下となるように加工精度を向上させると性能は さらに大きく向上することがわかる．近年の工作技術

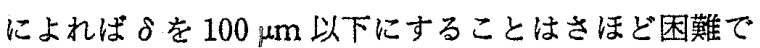
なく，また，パッキンなどによる漏えい防止法を採用 することにより十分性能向上を計ることができる。

駆動体の運動を 5 章で述べた解析法で計算し, その 結果を実験結果とともに図 7 に示した。図 7 の横軸は 経過時間 $t$, 縦軸は駆動体の変位 $z$ を表していて,い ずれも等速運動となるまでの様子を示している．実験 装置，および計算に用いた主なパラメータを表 1 に示 す. 表 1 中 $\mathrm{I} \sim \mathrm{IV}$ は設定の種類を表し, 添字の $E$ は 実験を示す.ここで定数 $f$ の值は実験曲線 $\mathrm{I}_{E}$ の結果 から算定した。計算に使用したポりトロープ指数 $n$ は $n=1.2$ を採用した ${ }^{(4)}$. 実験曲線 $\mathrm{II}_{E}$ と $\mathrm{III}_{E}$ は管路長さ $l=1.5 \mathrm{~m}$ を $l=0.4 \mathrm{~m}$ に短縮して圧力損失を小さく し $p_{H}$ の值を上昇させた結果を示す. 理論曲線 II と III は管路長を $l$ を $1.5 \mathrm{~m}$ に保ち, $p_{1}$ を $p_{1}=709 \mathrm{kPa}$ と したときの結果を示す. 実験では駆動体は圧力によっ て多少持ち上げられ，しかも十分な潤滑がなされてい るので, 駆動体とレールとの間のクーロン摩擦力は非 常に小さくこれを無視した。

図 7 の曲線 I，II，III はいずれも複雑な条件を含む 難しい理諭計算であるにもかかわらず実験結果と多少 差異はあるもののよい一致をみた。このことから加工 精度を改善した場合の駆動特性を理論的に推定し得る ことが明らかとなった，曲線 IVとIV 向上させ, $220 \mu \mathrm{m}$ なるすきま $\delta を 50 \mu \mathrm{m}$ とした場合 の理論計算による推定結果を示す.このうち IV は一定
負荷 $F_{t}$ が零の場合であり，IV $F$ は $147 \mathrm{~N}$ なる一定負 荷 $F_{t}$ を加えた場合のものである。このようにすきま $\delta$ を $50 \mu \mathrm{m}$ とすることにより，Ft が零の場合は曲線 I がIVに示すようにかなり速度が上昇する. また負荷 すなわち運搬能力は曲線 I と IV $F$ の比較からわかる ように $\delta$ を $50 \mu \mathrm{m}$ とすることにより $147 \mathrm{~N}$ と向上す る.

図 8 は駆動体の加工精度を表すすきま $\delta$ をパラメ 一タとして理論的に求めた性能曲線図である．図 8 の 綐軸は負荷 $F_{t}$ を，横軸は駆動体がほ伊等速運動とな

\begin{tabular}{|c|c|c|c|c|c|c|c|}
\hline & $\begin{array}{l}1 \\
\mathbf{m}\end{array}$ & $\underset{4 \mathrm{~m}}{8}$ & $\mathrm{~F}_{\mathrm{N}}$ & ${ }_{k P} P_{2}^{\prime}$ & $x \cdot g^{f} / 4$ & $\begin{array}{c}P_{3}=P_{4} \\
k P_{2}\end{array}$ & ${ }_{k P_{z}}^{P_{1}}$ \\
\hline 18 & \multirow{2}{*}{1.5} & \multirow{2}{*}{220} & \multirow{2}{*}{0} & \multirow{2}{*}{582} & - & 172 & 130 \\
\hline 1 & & & & & 29.4 & 175 & 132 \\
\hline II & 0.4 & \multirow{2}{*}{220} & \multirow{2}{*}{0} & - & - & 211 & 151 \\
\hline I & 1.5 & & & 709 & 29.4 & 211 & 151 \\
\hline III : & 0.4 & \multirow{2}{*}{220} & \multirow{2}{*}{5.89} & - & - & 209 & 150 \\
\hline 프 & 1.5 & & & 709 & 29.4 & 209 & 150 \\
\hline $\mathrm{N}$ & \multirow{2}{*}{1.5} & \multirow{2}{*}{50} & 0 & \multirow{2}{*}{582} & \multirow{2}{*}{29.4} & \multirow{2}{*}{389} & \multirow{2}{*}{381} \\
\hline $\mathrm{N}=$ & & & 147 & & & & \\
\hline
\end{tabular}

表 1 計算に用いたまなパラメータ

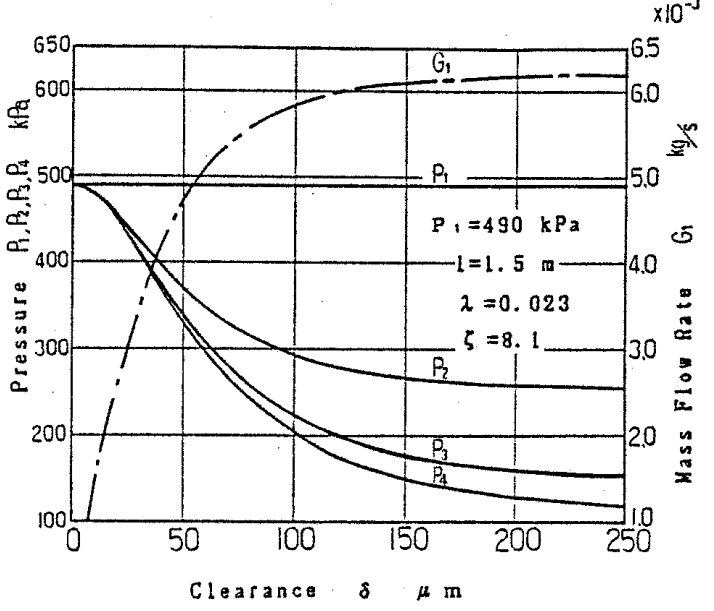

図 6，漏えいすきまと圧力および流量低下

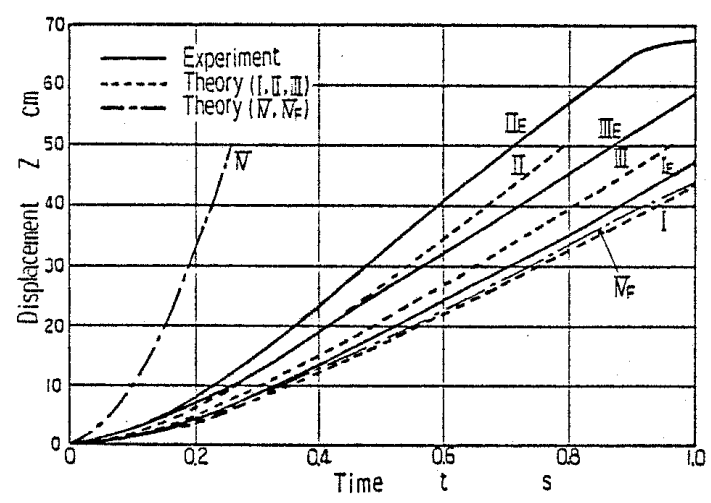

図 7 駆動体の運動 


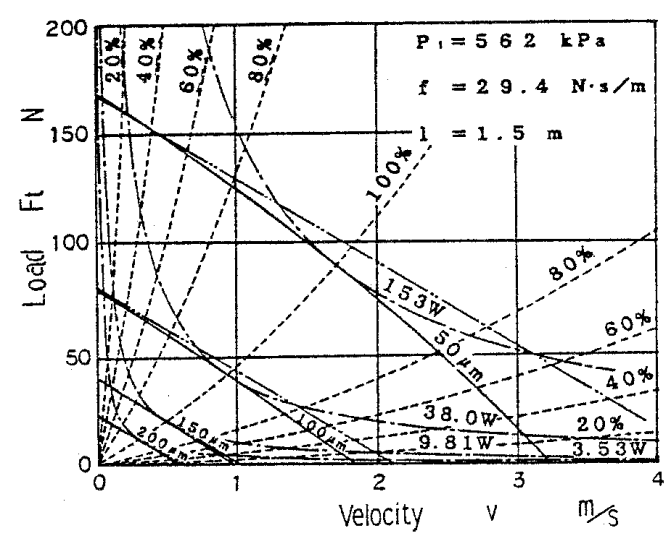

図 8 等仕事率曲線

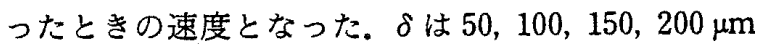
の 4 種類を選んだ. 図 8 中の一点鎖線は等仕事率曲線

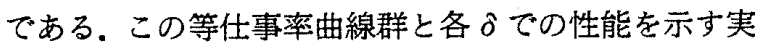
線群との接点を通る破線上では駆動体は最大の仕事率 を発揮することとなりこれを $100 \%$ と表現した。こ れを基準に 20 80\%の原点を通る破線群が記入され ている．図 8 から加工精度を高めることにより，どの 程度の性能向上が図られるかが明らかとなった。なお 図 8 中の二点鎖線は 6 章で述べた計算によって得た結 果を示す.
8. 結言

特殊な構造の空気圧リニアアクチニエータを提案, 試作し, 装置の性能試鈳を実施した。この結果を理論 解析結果と比較検討したが, 複雑な解析にもかかわら ず両者には比較的良好な一致が見られた。

装置は初めての試作であるため，十分な加工精度が 得られず，速度ならびに推進力が弱く，性能の向上が 必要であった。そのため, 理論解析から性能向上に必 要な加工精度を計算した結果，U 字形溝レール底面の ラック形状溝の寸法は試作装置では精度が $200 \mu \mathrm{m} て ゙$ あるのに対し，50 $\mathrm{m}$ 程度に向上させることにより， 十分実用に供し得る装置ができることが認められた。

終わりに装置の試作にご援助いただいたライン工業 侏に感謝の意を表する。

\section{文献}

(1) 例之ば, Bird, P. J., Electric versus hydraulics versus pneumatics, (1985), 77, Mech. Eng. Publications Limited.

（2）日本規格協会編，JIS ハンドブック油圧・空気圧，（昭和 54），350，日本規格協会.

（3）中島, 空気圧技術読本，(昭 49)，21，才一公社.

（4）辻・水本, 機講論, No. 216 (昭 44-10), 235. 